\title{
Jejak Perempuan Buruh Migran dalam Masyarakat ASEAN 2015
}

\author{
Desintha Dwi Asriani ${ }^{1}$ \\ Ezka Amalia ${ }^{2}$
}

\begin{abstract}
In the embodiment blueprint of ASEAN Community 2015, there are three important elements of the political and security pillar, the pillar of economic, social and cultural pillars. Are assumed to be mutually reinforcing. However, before the ASEAN Community currently limited to realizing economic growth and defense. Women migrant workers issues such precisely NOT SIGN hearts 8 Sector The services will be liberalized. Writing the initials of the Women's Studies That puts the migrant workers Astra Honda Motor as ISU Main hearts ASEAN Community Discourse 2015. Article Search Google using secondary data analysis approach, cCritical notes the issue of women migrant workers and the opportunities that may be managed critically describe.
\end{abstract}

\section{Keywords:}

ASEAN Community; women migrant workers; regional commitment.

\begin{abstract}
Abstrak
Komitmen negara-negara anggota ASEAN untuk mewujudkan sebuah masyarakat bersama yaitu Masyrakat ASEAN dituangkan melalui beberapa Cetak Biru Masyarakat ASEAN 2015Dalam. cCetak biru perwujudan Masyarakat ASEAN 2015 terdapat yang juga merupakan perwujudan tiga pilar Masyarakat ASEAN 2015tiga elemen penting yakni yaitu pilar politik dan keamanan, pilar ekonomi, dan pilar sosial budaya. Yang diasumsikan akan saling menopang. Namun, tersebut saling beririsan dalam berbagai hal. Sayangnya, wacana mewujudkan Masyarakat ASEAN saat ini baru sebatas mewujudkan Masyarakat Ekonomi ASEAN 2015. Upaya pemerintah negara anggota ASEAN untuk menggenjot pertumbuhan maupun pertahanan ekonomi.inya agar nantinya menjadi pemenang dalam Masyarakat Ekonomi ASEAN seringkali melupakan bahwa ada dinamika sosial budaya di dalamnya yang juga harus menjadi perhatian. Isu bBuruh migran perempuan khususnya misalnya perempuan yang merupakan salah satu entitas yang bekerja dalam bidang jasa justru tidak masuk ke dalam 8 bidang jasa yang nantinya akan diliberalisasikan. Hal ini tidak kemudian menjadikan mereka menjadi entitas yang dianaktirikan.

Tulisan ini merupakan kajian yang menempatkan perempuan buruh migran tersebut sebagai isu utama dalam wacana masyarakat ASEAN 2015. Dengan menggunakan pendekatan analisis data sekunder, catatan kritiits persoalan perempuan buruh migran dan peluang yang mungkin dikelola diuraikan secara kritis.
\end{abstract}

\footnotetext{
1 Dosen Jurusan Sosiologi Fisipol, UGM Yogyakarta

Email: desintha.dda@gmail.com

2 Alumni Jurusan Ilmu Hibungan Internasional Fisipol UGM Yogyakarta.
} 
Kata kunci:

masyarakat ASEAN; perempuan buruh migran; komitmen regional.

\section{Pendahuluan}

Tulisan ini berupaya untuk memberikan catatan kritis terhadap fenomena tenaga kerja perempuan dalam diskusi masyarakat ASEAN 2015. Hal ini terkait dengan berbagai dampak yang tidak sederhana seiring dengan pertumbuhan kesepakatan regional tersebut. Masyarakat ASEAN, meskipun sebuah gagasan untuk mengangkat isu-isu lokal sebagai basis pengetahuan, realitasnya banyak kebijakan yang masih digerakan secara politis oleh sejumlah elite. Kondisi ini bisa dipahami karena kehendak untuk melakukan percepatan pertumbuhan ekonomi bersama pada level regional. Namun tidak dapat dipungkiri juga bahwa berbagai praktek yang terkait dengan masyarakat ASEAN 2015 akan memberi dampak yang cukup besar pada aspek sosial. Jika gagasan regional ini berhasil maka tidak perlu ada yang dikhawatirkan. Sebaliknya, jika banyak persoalan yang justru muncul maka ini akan menjadi tantangan bersama yang penting untuk dikaji secara kritis. Oleh karena itu, memunculkan diskusi-diskusi berbasis pada pengalaman lokal bertemu relevansinya di sini, terutama soal perempuan.

Seperti diketahui bahwa wacana-wacana tentang perempuan secara sosiologis akan bertemu pada kritik terhadap relasi-relasi yang timpang. Dalam konstruksi gender misalnya, perempuan sering dihadapkan pada kondisi-kondisi yang tidak menguntungkan. Perempuan sering dijadikan sebagai target definisi tentang apa yang menjadi perannya dan bagaimana seharusnya menjadi perempuan. Perempuan yang seolah-olah tidak memiliki pilihan lantas semakin bermasalah ketika mereka terjebak pada kondisi kemiskinan. Perempuan berada dalam persimpangan antara tunduk pada kesepakatan kultural atau melawan arus untuk bekerja ke luar rumah. Pada titik tertentu bekerja di ranah publik kemudian dimaklumi tapi ternyata jejak dikotomi itu justru berpindah sehingga tidak banyak peluang perempuan untuk benar-benar berhasil di ranah kerja.

Demikian halnya dalam perspektif hubungan internasional bahwa perempuan tidak memliki peran di dalamnya sehingga tidak dibutuhkan untuk men-gender-isasi bagaimana kita menganalisis hubungan internasional (Jan Pettman 2001). Oleh karena itu, teori-teori feminis di dalam ilmu hubungan internasional menjadikan kondisi tersebut sebagai titik awal untuk memberikan alternatif kacamata dalam melihat hubungan internasional dari sudut pandang kelompok yang secara sistem terpinggirkan, misalnya dalam studi politik ekonomi global dan proses pembangunan.

Sejak restrukturisasi ekonomi global di tahun 1970, kita telah menyaksikan perubahan dalam sistem tata kerja perusahaan-perusahaan multinasional. Perusahaan-perusahaan multinasional tersebut memindahkan proses produksinya ke negara-negara berkembang untuk mendapatkan tenaga kerja buruh yang lebih banyak dan lebih murah. Perempuan menjadi pilihan yang diutamakan untuk dipekerjakan dikarenakan keterampilan jari-jari mereka (nimble fingers), lebih patuh, kemungkinan kecil untuk mengikuti perserikatan buruh serta dapat digaji rendah. Fenomena yang dinamai "feminisasi" tenaga kerja ini menunjukkan bagaimana perempuan sangat rentan di dalam kebijakan pasar karena gaji mereka yang lebih rendah daripada pekerja laki-laki dan jam kerja yang lebih lama.

Selain itu, di saat yang sama, negaranegara berkembang yang menjadi tujuan perusahaan-perusahaan multinasional sebagai tempat proses produksi masih mengalami defisit neraca pembayaran, inflasi yang tinggi, serta pertumbuhan ekonomi yang rendah. Hal ini yang mendasari negara-negara tersebut 
meminta bantuan keuangan dari lembaga moneter internasional yaitu IMF. Program structural adjustment yang mennjadi syarat dari IMF untuk negara-negara peminjam tersebut mendorong terjadinya feminisasi kemiskinan menurut Jacqui True. Feminisasi kemiskinan inilah yang mendorong para perempuan untuk ikut ambil bagian dalam mencari nafkah dengan menjadi buruh migran sebagai misalnya pembantu rumah tangga.

Seiring dengan perkembangan jaman, profesi menjadi buruh migran semakin diminati karena gaji yang lebih besar dibandingkan dengan bekerja di pabrik. Dalam wacana Masyarakat ASEAN, Mutual Recognition Agreement (MRA), ASEAN Framework Agreement on Services (AFAS) dan ASEAN Agreement on the Movement of Natural Persons (MNP) hanya mengatur perpindahan tenaga kerja terampil dimana para buruh migran tidak masuk ke dalamnya.

Oleh karena itu, tulisan ini kemudian akan lebih banyak melihat tantangan sekaligus peluang yang dimiliki perempuan buruh migran di tengah-tengah keberadaan masyarakat ASEAN 2015. Hal ini juga untuk memberikan catatan kritis tentang komitmen masyarakat ASEAN untuk membentuk komunitas masyarakat yang peduli dan akan menangani beberapa isu penting khususnya mempromosikan partisipasi yang sama bagi perempuan dalam proses pembangunan melalui penghilangan seluruh bentuk diskriminasi. Secara operasional, masyarakat ASEAN, khususnya Masyarakat Ekonomi ASEAN di tahun 2015 akan ada sekitar 8 sektor pekerjaan jasa yang dibuka untuk persaingan bebas seluruh negara anggota ASEAN. Namun, tanpa kesadaran dari kelompok perempuan atas perubahan-perubahan dalam kebijakan maupun kondisi ekonomi regional di Asia Tenggara, maka kesenjangan akan semakin lebar dan perempuan rentan untuk terus menjadi kelompok terpinggirkan dan dirugikan.

\section{Metode}

Kajian ini merupakan olahan beberapa data sekunder dari penelitian tentang sense of community masyarakat ASEAN 2015 yang pernah dilakukan sebelumnya. Sehingga secara metodologi, tulisan ini berasal dari sebuah penelitian dengan pendekatan studi literatur yakni berupa data-data kuantitatif dan penelusuran beberapa dokumen terkait. Data sekunder yang diambil di sini salah satunya adalah berbasis dari penelitian lapangan yang dilakukan oleh peneliti kepada sejumlah 400 responden di Yogyakarta. Tulisan ini hanya mengambil beberapa data terkait dengan perbedaan persepsi, pengetahuan serta pengalaman perempuan dan laki-laki terhadap masyarakat ASEAN 2015. Hal ini dimaksudkan untuk lebih menggali informasi dari sisi perempuan yang diasumsikan berbeda dengan laki-laki.

Selanjutnya, untuk memperkaya analisis, data-data sekunder dari beberapa dokumen yang ada juga disertakan. Hal ini dimaksudkan untuk memperdalam data dari kasus yang ingin diproblematisasi. Selain itu, data-data dari dokumen tersebut juga dapat digunakan untuk mempertajam konteks dari kajian yang sedang dilakukan.

\section{Isu Migrasi pada Dikotomi Perempuan Utara dan Perempuan Selatan}

Dalam beberapa pendekatan studi migrasi, ada sejumlah alasan mengapa perpindahan dari satu daerah ke daerah lain sering dianggap sebagai cara penting untuk bertahan hidup. Dalam logika umum dapat dikatakan bahwa motif ekonomi atau imajinasi kesejahteraan yang lebih baik sering menjadi alasan dasar sekelompok manusia untuk melakukan migrasi. Namun dalam skema pembangunan, migrasi tentu tidak lagi dipandang sebagai persoalan teknis belaka. Migrasi mungkin saja dipandang hinggal level politik untuk memenangkan scenario negara tertentu. Dalam 
relasi negara-negara utara dan selatan misalnya, pembangunan ekonomi dengan menjadikan migrasi tenaga kerja sebagai salah satu cara sering hanya berhenti pada orientasi kejayaaan negara-negara utara. Akan tetapi agenda untuk juga memajukan negara-negara selatan sebagai pengirim tenaga kerjanya masih sangat terbatas. Apalagi jika dihubungkan dengan kondisi pada tenaga kerja migran itu sendiri (Anich, Crush, Melde, Oucho 2014). Alih-alih mendapatkan hasil sesuai dengan impiannya tentang kesejahteraan, mereka justru sering harus menerima berperan sebagai tenaga kerja berupah rendah sekaligus murah.

Dikotomi antara negara utara dan negara selatan ini juga lekat dalam konteks perempuan buruh migran. Perkembangan masyarakat industri yang membutuhkan banyak sekali tenaga kerja murah telah menggerus negaranegara yang tidak memiliki posisi tawar yang kuat. Negara-negara selatan di sini kemudian sering disebut-sebut sebagai objek dari negara-negara utara yang memiliki modal dan dominasi yang lebih besar. Daerah yang disebutkan sebagai wilayah selatan dianggap sebagai bekas jajahan negara industri utara yang dapat dieksploitasi. Justifikasi inilah yang kemudian melahirkan asumsi bahwa manusia negara-negara selatan dapat dipekerjakan dengan upah yang minimal. Ketergantungan negara selatan yang cenderung tidak memiliki alat produksi menjadi sulit untuk bertahan selain menyerahkan tenaga kerja murahnya sebagai upaya untuk mengikuti skema eknomi global (Moose 2007).

Chafezt (2006) juga menegaskan bahwa sistem dunia yang seolah-olah membelah negara menjadi negara maju dan negara pinggiran telah menjadi landasan untuk meniadakan peran utama perempuan di sektor ekonomi. Penetrasi kapitalisme yang kuat semakin meningkatkan ketidaksetaraan gender yang sebelumnya sudah dibentuk secara konstruktif oleh struktur patriarki. Sehingga pada kondisi praksisnya, perempuan mengalami berlapis objektifikasi yakni dari patriarkhi itu sendiri dan agen-agennya yang kemudian berkuasa pada ranah industri yang kapitalistik.

Perbedaan peran antara negara utara dan negara selatan ini secara umum memberikan dampak yang sama terhadap tenaga kerja laki-laki maupun perempuan. Mereka terjebak pada keterputusan imajinasi kesejahteraan dan peluang untuk memenuhinya. Modernisasi menciptakan ukuran-ukuran baru tentang pertumbuhan, kemajuan dan kesejahteraan. Dapat dikatakan segalanya diukur dengan satuan yang sama yakni harga atau materi. Maka dengan menggantungkan harapan pada pendapatan sebagai tenaga kerja, mereka seolah tidak memiliki pilihan. Dengan keterbatasan kapasitas dan jaminan negara, mereka tetap bersedia diupah rendah daripada sama sekali tidak mendapatkan penghasilan. Sehingga kemiskinan menjadi dampak yang lebih akrab dibandingkan dengan kesejahteraan yang diimajinasikan sebelumnya. Dan kondisi ini hampir dialami oleh seluruh jenis kelamin.

Akan tetapi, dalam wacana global, persoalan yang dialami perempuan cenderung lebih beragam jika dibandingkan dengan laki-laki. Perkembangan industri global yang memberikan perubahan pada skema dunia kerja memberikan pengaruh yang tidak tunggal bagi perempuan. Di satu sisi, perempuan sama halnya dengan laki-laki yang mengalami kemiskinan dan keterbatasan akses terhadap sumber daya manusia. Namun secara khusus, perempuan juga mengalami apa yang dinamakan dengan diskriminasi berbasis gender. Moose (2007:112) misalnya menguatkan argumen ini dengan menyatakan bahwa perempuan sejatinya mengalami tiga lapis penindasan sekaligus. Penindasan tiga lapis tersebut terletak pada posisinya sebagai anggota suatu bangsa tertindas di tanah kelahirannya, sebagai anggota kelas pekerja atau petani tak memiliki tanah dan sebagai perempuan yang tunduk terhadap diskriminasi 
dalam perkawinan, hak atas kekayaan dan akses pelayanannya menjadi terbelenggu.

Mitchel (dalam Tong 1998) juga menegaskan bahwa perempuan berada dalam belenggu dua struktur sekaligus yakni patriarki dan kapitalisme. Meskipun bagi feminis Marxist lebih menyukai untuk menempatkan perempuan sebagai bagian dari kondisi diskriminasi yang lebih umum, Mitchel sebagai feminis sosialis memberikan peringatan yang lebih mendalam. Patriarki dan kapitalisme sama-sama melihat objek sebagai alat untuk dieksploitasi. Sehingga perempuan akan sekaligus mengalami opresi ganda yakni dari patriarki yang lebih melihat laki-laki sebagai subjek publik dan kapitalisme yang akan selalu menempatkannya sebagai objek. Kesempatan perempuan untuk masuk ke dalam ranah publik menjadi seperti sebuah pencapaian semu. Perempuan selain harus mendapatkan upah yang rendah, mereka juga masih harus mengalami sejumlah ketidakadilan.

Indonesia misalnya, dalam hal ini menjadi salah satu negara penghasil tenaga kerja murah yang cukup besar. Persoalan patriarki juga masih menjadi bagian yang lekat di masyarakat ini. Hal ini tampak pada fenomena feminisasi kerja yang hampir tak terhindarkan. Peluang perempuan untuk berpartisipasi di ranah kerja sama halnya dengan negara dunia ketiga lainnya memang telah diberikan. Mereka diberikan peluang untuk juga menjadi tenaga kerja yang berpenghasilan. Sehingga sekilas dalam perjuang mencapai kesejahteraan, perempuan tidak jauh berbeda dengan lakilaki. Namun kultur patriarki yang begitu dalam terinternalisasi sama sekali tidak memberikan pembebasan bagi perempuan. Mereka diterima sebagai pekerja namun tetap saja ditempatkan di wilayah-wilayah yang merepresentasikan aktivitas domestik. Buruh perempuan hanya diberikan kepercayaan untuk mengerjakan hal-hal yang membutuhkan ketrampilan, kehatian-hatian dan ketelatenan. Pekerjaanpekerjaan yang membutuhkan kemampuan untuk mengambil keputusan, memimpin dan kompetitif tetap diidentikkan dengan pekerja laki-laki. Laki-laki masih dianggap sebagai subjek yang memimpin, mendominasi dan menentukan. Maka, sejauh apapun perempuan melibatkan dirinya di ranah kerja, mereka tetap memiliki keterbatasan untuk mendapatkan pengembangan karir. Sehingga, banyaknya tenaga kerja perempuan yang berpartisipasi di ranah publik hanya akan menjadi buruh upahan yang terus berisiko untuk didiskriminasi dan dieksploitasi.

Jika ditarik pada konteks global kontemporer, maka realitas feminisasi buruh ini salah satunya diwujudkan dalam tingginya jumlah TKW yang dikirimkan ke luar negeri. Pada kasus ini Indonesia merupakan salah satu negara dengan jumlah TKW yang cukup besar. Keterlibatan Indonesia dalam ekonomi global justru lebih banyak menarik perempuan untuk menjadi buruh yang rentan dengan berbagai risiko. Dalam beberapa kasus buruh migran, banyak TKW yang tidak memiliki kemampuan negosiasi yang baik sehingga semakin terjerumus ke dalam persoalan yang lebih sulit. Hal ini masih ditambah dengan beban kultural yang harus ditanggung di dalam keluarganya tentang konstruksi peran domestik perempuan. Hampir tidak ada jaminan secara kultural juga bahwa perempuan akan dibela atau dibantu ketika mereka bagi bermasalah di ranah publiknya. Sebab meskipun berada dalam keterpurukan ekonomi, masyarakat masih sulit untuk menghilangkan keterlekatan perempuan dengan tugas utamanya sebagai manusia domestik. Sehingga, ketika perempuan menanggung risiko di luar rumahnya, hal itu seolah-olah dianggap sebagai hukuman yang dilumrahkan.

Realitas tentang ketimpangan relasi dalam fenomena buruh migran tersebut, meskipun terdapat catatan Master Plan on Connectivity tentang dorongan meningkatkan ketrampilan pekerja domestik dan kemudian dipertajam pada catatan ASEAN Woman 
Committee, tampaknya masih terjadi. Hal ini dapat ditunjukan dalam beberapa catatan jumlah perempuan yang menjadi buruh migran dan sejumlah berita buruk tentang rendahnya posisti tawar perempuan buruh dalam kasuskasus pemenuhan hak-hak dasar pekerja dan huokum lainnya.

\section{Fenomena Buruh Migran: Fenomena Regional}

Fenomena buruh migran dapat dikatakan lahir bersamaan dengan berkembangnya ide tentang indusrialisasi. Orientasi pertumbuhan ekonomi dalam logika industri menstimulasi lahirnya beberapa kebijakan yang berdampak pada semakin tingginya jumlah masyarakat yang menjadi buruh bahkan di rumahnya sendiri. Hal ini misalnya yang terjadi pada sektor pertanian. Ambisi untuk memiliki peran dalam perekonomian global, maka industri pertanian diberlakukan untuk mendorong percepatan produksi. Sekilas, kebijakan ini tampak akan mendatangkan berlipat keuntungan namun ternyata idealisasi tersebut justru menjebak para petani pada ketidakberuntungan. Proses produksi dengan segala rekayasa industri, selain menggerus lokalitas petani juga membuat petani justru menjadi miskin. Harga produksi yang diberikan tidak selalu sebanding dengan nilai jual hasil panennya. Maka, para pemodal yang lebih mampu membiayai proses produksi semacam ini lantas mengambil alih dan menggeser para petani yang tadinya pemilik menjadi buruh di ladangnya sendiri. Kritik terhadap lahirnya logika industri atau yang sering dibingkai dengan istilah revolusi hijau ini sebetulnya juga dikritik oleh negara berkembang lainnya. Shiva (1997) misalnya menganggap bahwa revolusi hijau telah benar-benar telah merampas sumber daya dari mereka yang benar-benar memiliki dan membutuhkan.

Di Indonesia, dampak buruh dari industrialisasi semakin terpuruk ketika negara mengalami krisis dan harus membayar sejumlah kompensasi terhadap pasar global. Maka pemerintah akhirnya membangun basis perekonomian beralaskan tenaga kerja murah di dalam negeri untuk menarik penanaman modal luar negeri dan berangkat melalui sebuah program mengekspor tenaga kerja (Komnas Perempuan 2003)

Hal yang menarik adalah ekspor buruh migran Indonesia ini justru perempuan yang memiliki sumbangsih yang besar. Dalam sejarahnya memang sudah seperti menjadi isu yang wajar (mindstream) bahwa banyak perempuan yang bersedia menjadi buruh migran untuk bekerja sebagai pembantu rumah tangga, seperti yang ditunjukan pada data berikut ini:

\begin{tabular}{lcc}
\multicolumn{3}{c}{$\begin{array}{c}\text { Pekerjaan dan Tujuan Buruh Migran } \\
\text { Indonesia }\end{array}$ 1997 (\%) } \\
\hline \multicolumn{1}{c}{ Pekerjaan } & Timur & Asia \\
& Tengah & \\
\hline Pembantu Rumah Tangga & 81.13 & 53.49 \\
Supir & 13.21 & 0.00 \\
Buruh Bangunan & 3.77 & 4.65 \\
Operator & 0.00 & 6.98 \\
\hline
\end{tabular}

Sumber: Komnas Perempuan 2003 (dalam Laporan.Indonesia kepada Pelopor Khusus PBB 2002

Jejak dikotomi peran antara laki-laki dan perempuan di ranah publik jelas terlihat disini. Jika dalam konteks buruh pabrik misalnya, banyak tenaga kerja perempuan diorientasikan pada kerja-kerja berkarakter feminin, maka demikian juga dalam skema global. Nilai patriarki sedikit banyak telah mengatur perempuan yang baik adalah yang patuh dan menurut. Dalam budaya yang seperti ini, perempuan sering tumbuh menjadi manusia yang terbiasa untuk tidak menuntut. Pada konteks ini, para pengusaha dan pemodal sering memanfaatkan bentukan budaya tersebut sebagai alasan untuk menempatkan para perempuan pada pekerjaan-pekerjaan domestik dan tentunya dengan upah rendah. 
Asumsinya perempuan dianggap tidak akan berani untuk menuntut atau memprotes jika mendapati kondisi yang tidak sesuai dengan haknya (Sunarijati:2007).

Kencederungan buruh migran perempuan sebagai pekerja domestik di luar negeri ini masih cukup populer hingga saat ini. Pada lima besar pekerjaan buruh migran Indonesia, peringkat pertama ditempati oleh pekerja domestik seperti dalam tabel berikut ini:

\begin{tabular}{ccc}
\multicolumn{3}{c}{$\begin{array}{c}\text { Penempatan Tenaga Kerja Luar Negeri } \\
\text { Indonesia Berdasar Jenis Pekerjaan } \\
\text { Tahun 2014 (ribu) }\end{array}$} \\
\hline $\begin{array}{c}\text { Nomor } \\
\text { Urut }\end{array}$ & Jenis Pekerjaan & Jumlah \\
\hline 1 & Pekerja Domestik & 113.952 \\
2 & Pengasuh/Care Taker & 40.581 \\
3 & Pekerja Perkebunan & 40.146 \\
4 & Operator & 32.819 \\
5 & Pekerja Kapal (Deck & 8.904 \\
\hline
\end{tabular}

Sumber: Subbid Pengelohan Data, Bidang Pengolahan dan Penyajian Data (Puslitfo BNP2TKI) dalam www. bnp2tki.go.id

Dalam tabel tersebut tampak bahwa jumlah pekerja domestik dan pengasuh orang tau atau orang sakit (care taker) cukup besar yakni 113.952 dan 40.581 . maka dapat dikatakan bahwa dalam kurun waktu hampir 10 tahun, orientasi terbeesar pekerjaan para buruh migran belum juga berubah. Mereka seolah-olah hanya memilki peluang dalam pekerjaan-pekerjaan yang berupah rendah serta dekat dengan berbagai persoalan diskriminatif. Hal ini menjMaka menjadi seperti lumrah dalam dinamika pekerjaan internasional, sehingga Indonesia tidak ragu untuk mengirim tenga kerja perempuannya. Perempuan seolah-olah lebih memiliki peluang untuk bekerja di luar negeri dengan selisih kurs sehingga pendapatannya tampak lebih banyak dibanding bekerja di negara sendiri dengan jenis pekerjaan yang sama. Namun jika dilihat secara lebih mendalam tentu ini sulit untuk dimaknai sebagai prestasi. Di sini perempuan dengan kapasitas yang rendah dipekerjakan sebagai pembantu rumah tangga hanya karena konstruksi yang menempatkan perempuan seolah-olah hanya dapat menjalankan peran domestik. Sejak awal, patriarki telah membatasi ruang, ambisi dan cita-cita perempuan. Sejauh perempuan melangkah dan setinggi apapun perempuan bercita-cita, kesepakatan kultural tetap hanya akan menempatkan perempuan sebagai makhluk domestik. Maka kesediaan untuk menerima perempuan bekerja di luar negeri sebagai buruh sebetulnya bukan untuk memenuhi hak asasi perempuan sebagai manusia. Namun lebih karena perempuan merupakan objek yang mudah untuk dieksploitasi tenaganya.

Sementara itu, fenomena migrasi tenaga kerja secara global telah mengalami peningkatan dalam kurun dua dekade terakhir. Menurut International Organization on Migrant di tahun 2010, satu per tiga dari keseluruhan tenaga kerja migran global berasal dari negaranegara Asia (61 juta dari 214 juta tenaga kerja migran) dan lebih dari setengahnya merupakan perempuan. Banyak alasan yang menjadi landasan mengapa para perempuanperempuan tersebut memutuskan untuk menjadi tenaga kerja migran seperti kesempatan ekonomi yang lebih baik dibandingkan di daerah asal, dan bahkan karena alasan terpikat kehidupan glamor di kota maupun di negara lain. Seringkali kelompok perempuan yang menjadi tenaga kerja migran ini tidak memiliki kemampuan yang spesifik yang menyebabkan mereka pada akhirnya bekerja sebagai pembantu rumah tangga, pekerja pabrik, buruh pertanian, bahkan pekerja seks komersial (Leon 2014).

Di satu sisi, fenomena ini memberikan keuntungan baik bagi negara asal pengirim, negara penerima, dan perempuan sendiri. Bagi negara asal pengirim tenaga kerja migran, melalui pengiriman tenaga kerja migran ke 
luar negeri, negara tersebut akan mendapatkan remitansi. Bagi negara penerima tenaga kerja migran, mereka diuntungkan secara ekonomi dari terpenuhinya jumlah tenaga kerja yang mereka butuhkan hingga pertumbuhan ekonomi negara penerima. Selain itu, bagi perempuan sendiri, menjadi tenaga kerja migran dinilai dapat menyamakan status sosial mereka dengan laki-laki, meraih kemandirian ekonomi dan meningkatkan kepercayaan diri. Di sisi lain, fenomena tenaga kerja migran ini juga membawa permasalahanpermasalahan tersendiri, terutama bagi para perempuan yang menjadi tenaga kerja migran. Perempuan rentan terkena tindakan-tindakan yang diskriminatif, penyiksaan baik secara fisik maupun verbal, hingga menjadi korban perdagangan manusia.

Sebagai salah satu negara dengan jumlah penduduk terbanyak di dunia, menjadikan Indonesia menjadi salah satu negara yang mengalami surplus tenaga kerja. Pada bulan Agustus 2013, menurut data statistik Badan Pusat Statistik Indonesia tercatat sekitar 118,19 juta masyarakat Indonesia yang termasuk dalam angkatan kerja. Sayangnya meskipun Indonesia menikmati pertumbuhan ekonomi dalam beberapa kurun waktu terakhir, ada sekitar 7,39 juta dari keseluruhan jumlah angkatan kerja tersebut yang saat ini tidak bekerja (BPS 2013). Jumlah ini meningkat jika dibandingkan data pada bulan Mei 2013 ketika angka pengangguran berada di titik paling rendah yang pernah dicapai oleh Indonesia dalam satu dekade terakhir yaitu 5,8 persen atau sekitar 7.068 .519 orang dengan angka pengangguran perempuan sekitar 6,3 persen dari keseluruhan angkatan kerja perempuan (ILO 2013). Dari keseluruhan jumlah angkatan kerja tersebut banyak dari mereka yang pada akhirnya memutuskan untuk menjadi tenaga kerja migran di berbagai negara di dunia. Hal ini tidak dapat dilepaskan dari masih tingginya angka kemiskinan di Indonesia dan tidak memenuhinya jumlah lapangan kerja di dalam negeri. Dengan bekerja di luar negeri, para tenaga kerja migran terutama kelompok perempuan memiliki harapan untuk kehidupan yang lebih baik.

Di wilayah Asia Tenggara sendiri, Indonesia merupakan negara kedua terbesar dalam hal jumlah tenaga kerja migran di Asia Tenggara setelah Filipina (IOM 2010). Selain kedua negara tersebut, Laos, Vietnam, Kamboja, Myanmar juga merupakan negara pengirim tenaga kerja migran di Asia Tenggara dengan Malaysia sebagai negara baik pengirim maupun penerima tenaga kerja migran meskipun pertumbuhan ekonomi Malaysia dapat dikatakan sebagai sebuah kesuksesan yang sayangnya tidak diimbangi dengan jumlah surplus tenaga kerja.

Hal ini menjadi wajar, mengingat pengiriman tenaga kerja ke luar negeri menguntungkan bagi Indonesia maupun negara-negara lain di Asia Tenggara dari sisi penerimaan remitansi. Sekitar 6,3 juta tenaga kerja asal Indonesia bekerja di luar negeri dan mereka mengirimkan remitansi ke Indonesia sekitar Rp 73 triliun di tahun 2013. Dari keseluruhan jumlah tersebut, sebagian besar merupakan perempuan dan bekerja di sektor rumah tangga ataupun jasa pelayanan karena mereka tidak memiliki keterampilan khusus yang dibutuhkan untuk bekerja di sektor formal (IOM 2010)

Tercatat pada tahun 2013, sekitar 512.168 orang tenaga kerja Indonesia ditempatkan di luar negeri untuk bekerja baik di sektor formal maupun informal (JPNN 2013). Jumlah ini mengalami peningkatan dibandingkan jumlah tenaga kerja Indonesia yang ditempatkan di tahun 2012 yaitu mencapai 494.609 orang (JPNN 2013). Dari total jumlah tenaga kerja migran yang dikirimkan pada tahun 2013 lalu, sebanyak 150.236 orang atau sekitar 29,3 persen bekerja di Malaysia (Liputan 6, 2013).

Banyaknya tenaga kerja Indonesia yang bekerja di Malaysia dibandingkan di negaranegara anggota ASEAN lainnya maupun 
negara-negara lain tidak dapat lepas dari pemahaman yang dimiliki oleh para tenaga kerja migran bahwa Indonesia dan Malaysia merup akan satu rumpun. Hal ini kemudian yang membuat para tenaga kerja migran tidak menemukan kesulitan untuk berkomunikasi dengan majikan mereka. Meskipun pada kenyataannya, alasan satu rumpun tidak lantas meniadakan persoalan yang dialami oleh para perempuan buruh migran. Banyak kasus seperti kekerasan juga banyak terjadi di Malaysia. Hal ini seperti yang dicatat oleh Komnas Perempuan (2012) bahwa antara tahun 2003-2005 banyak laporan seperti dari KBRI Jedah, Kuala Lumpur dan Johor tentang kekerasan yang dialamiai oleh para buruh migran. Jumlahnya sangat bervariasi bahkan seperti di Johor kasus kekerasan yang menimpa perempuan buruh migran bisa sampai 433 kasus (Komnas Perempuan 2006). Berbeda dibandingkan dengan negara ASEAN lainnya, seperti Singapura. Para tenaga kerja migran diharuskan memahami dua bahasa utama negara tersebut yaitu bahasa Inggris dan Mandarin. Jika para tenaga kerja migran tidak dapat menguasai dua bahasa tersebut, dapat dipastikan mereka akan mengalami kendala selama mereka bekerja di sana.

Dinamika para perempuan buruh migran di beberapa negara tersebut menujukan bahwa pekerjaan tersebut sangat berisiko. Terlebih jika dilihat dari latar belakang para perempuan buruh migran tersebut. Mereka cenderung memiliki keterbatasan pengalaman dan hanya berpendidikan rendah. Sehingga ketika mereka dihadapkan pada kasus-kasus yang mungkin merugikan, mereka sering sulit untuk melakukan negosiasi. Akibatnya, banyak perempuan buruh yang kembali harus terjebak pada tindak diskriminasi dan kekerasan. Hal ini tampak dalam beberapa kasus kekerasan perempuan buruh Indonesia. Mereka ratarata berkonflik dengan majikannya lantas terjerumus pada kasus-kasus kriminal. Bagi yang memiliki kemampuan bernegosiasi dan surat-surat resmi sebagai migran, biasanya akan lebih mudah mendapatkan bantuan meskipun tidak juga mudah. Sebaliknya jika mereka ternyata adalah pada perempuan yang tidak cukup memiliki pengalaman serta pengetahuan tentang hukum maka sering terjebak pada kondisi yang semakin menyudutkan. Mereka harus mengikuti aturan hukum negara tempat bekerja sementara negara asal yang juga tidak terlalu antisipatif baik secara politik maupun hukum seolah menjadi tidak dapat dijadikan sebagai sumber pertolongan.

Kondisi semacam inilah yang kemudian menjadi tantangan bersama dalam masyarakat ASEAN 2015. Keberdaaan negara-negara pengirim perempuan buruh migran yang kebetulan juga sebagai anggota masayarakat ASEAN penting untuk melihat ASEAN sebagai peluang strategis untuk mendiskusikan kasuskasus perempuan buruh migran ini secara lebih serius. Hal ini terkait dengan fakta yang terus menggerus perempuan sebagai tenaga kerja murah dibandingkan laki-laki meskipun dalam beban yang sama sehingga sangat rentan untuk meningkatkan feminisasi kemiskinan (Dunn dan Waller 1996 dalam Donahoe 1999). Jika kecenderungan meningkatnya kemiskinan kelompok perempuan ini tidak segera diatasi maka gagasan besar pertumbuhan ekonomi di level regional bisa jadi juga akan dipertanyakan keberhasilannya.

\section{Perempuan Melihat Masyarakat ASEAN}

Melalui Bali Concord II yang ditandatangani oleh negara-negara anggota ASEAN pada tanggal 7 Oktober 2003 menandai babak baru dalam sejarah perjalanan ASEAN. ASEAN berupaya untuk melangkah lebih jauh dengan membentuk Masyarakat ASEAN yang terdiri dari tiga pilar utama yaitu pilar politikkeamanan, pilar ekonomi dan pilar sosialbudaya. Dengan pembentukan Masyarakat ASEAN, diharapkan ASEAN mampu menjadi sebuah organisasi regional yang dinamis, kohesif dan tangguh demi kesejahteraan negara- 
negara anggota dan masyarakatnya. ${ }^{3}$ Selain itu, melalui pembentukan Masyarakat ASEAN, ASEAN juga ingin mengubah citra yang selama ini ditampilkan yaitu sebuah organisasi yang elitist, tidak ada keterlibatan masyarakat dalam setiap pembentukan kebijakan menjadi sebuah organisasi yang berorientasi masyarakat.

Setiap negara anggota ASEAN memiliki waktu yang cukup lama untuk melakukan sosialisasi atas pelaksanaan Masyarakat ASEAN yang awal mulanya akan dilaksanakan pada tahun 2020 dipercepat melalui Deklarasi Cebu mengenai Percepatan Pembentukan Masyarakat ASEAN pada tahun 2015. Sosialisasi ini diperlukan untuk meningkatkan tidak hanya kesadaran maupun pengetahuan masyarakat akan penerapan Masyarakat ASEAN, namun juga untuk meningkatkan rasa kepemilikan maupun we-feeling terhadap ASEAN. Inilah yang menjadi titik tolak upaya ASEAN untuk mewujudkan sebuah komunitas bersama yang saling peduli dan berbagi, serta diperkuat dengan penyusunan Cetak Biru (Blue Print) tiga pilar utama Masyrakat ASEAN, khususnya Cetak Biru Masyarakat Sosial dan Budaya ASEAN.

Sayangnya, kendati masing-masing kepala negara di ASEAN, termasuk Indonesia, telah menyatakan untuk menjalin kerjasama yang lebih erat dalam format Masyarakat ASEAN, masyarakat tidak sepenuhnya sadar atau memiliki sense identitas ASEAN yang cukup. Padahal, konstruksi identitas keASEAN-an penting dalam pembentukan sebuah regionalisme (Acharya, 2004). Selain itu, kesadaran warga tentang ASEAN juga penting untuk memastikan seberapa siap sebuah negara-terutama dalam hal ini Indonesia untuk menyambut Masyarakat ASEAN dan nantinya dapat keluar sebagai pemenang. Hal ini ditunjukan dengan hasil surveiy yang dilakukan Pusat Studi ASEAN Fisipol

3 http://www.asean.org/news/item/declaration-of-aseanconcord-ii-bali-concord-ii
UGM (2014) yang menyatakan bahwa dari 400 responden dengan komposisi 193 orang laki-laki dan 207 perempuan tersebut, hanya sekitar 39,3 persen dari keseluruhan responden yang mengetahui tentang rencana penerapan Masyarakat ASEAN. Hal ini menunjukkan betapa masih rendahnya kesadaran masyarakat atas rencana penerapan Masyarakat ASEAN di tahun 2015. Namun, hanya sekitar 44,3 persen dari keseluruhan responden menyatakan bahwa mereka tidak merasa menjadi bagian dari Masyarakat ASEAN. Jumlah tersebutlah yang harus mulai dikerjakan oleh pemerintah sebagai upaya untuk meningkatkan kesadaran, pengetahuan tentang Masyarakat ASEAN khususnya apa yang dapat mereka peroleh dari pelaksanaan Masyarakat ASEAN tersebut.

Dalam penelitian yang dilakukan oleh Pusat Kajian ASEAN di bulan September 2014 lalu, dari 400 responden yang terdiri dari pelajar, mahasiswa, pengusaha, akademisi, aktivis, seniman dan media, hanya sekitar 39,3 persen responden yang menyatakan mengetahui tentang rencana Masyarakat ASEAN dan sekitar 55,8 persen yang merasa menjadi bagian dari Masyarakat ASEAN. Dari 400 orang tersebut, 207 responden berjenis kelamin perempuan dan sisanya berjenis kelamin laki-laki. Hal ini memperlihatkan meskipun ASEAN melalui Rencana Kerja-nya memiliki berbagai tujuan dan upaya untuk mempromosikan partisipasi perempuan dalam proses pembangunan menuju sebuah Masyarakat ASEAN, masih banyak masyarakat khususnya kelompok perempuan yang belum mengetahui dan memahami benar apa yang akan terjadi saat Masyarakat ASEAN 2015 diterapkan.

Padahal perempuan seharusnya menjadi salah satu kelompok yang seharusnya menjadi fokus pemerintah dalam upaya meningkatkan kesadaran, pengetahuan terhadap Masyarakat ASEAN. Hal ini tidak bisa dilepaskan dari posisi perempuan yang seringkali termarjinalkan baik karena latar belakang budaya, kebijakankebijakan yang diterapkan sebuah negara. 
Dengan diterapkannya Masyarakat ASEAN, kelompok-kelompok yang tidak sadar, mengerti dan mengetahui tentang aturan mainnya pasti akan menjadi kelompok yang dirugikan. Mereka tidak akan mampu bersaing ketika Masyarakat Ekonomi ASEAN dibentuk dan membuka pintu persaingan lebih luas. Ketika hal ini dikaitkan dengan tenaga kerja migran Indonesia, dengan kondisi bahwa kebanyakan tenaga kerja migran Indonesia merupakan tenaga kerja migran yang tidak memiliki keterampilan khusus dan 75 persen dari mereka merupakan perempuan, maka mereka akan menjadi pihak yang kalah jika dibandingkan dengan tenaga kerja migran dari negara-negara anggota ASEAN khususnya Filipina yang memiliki keterampilan lebih baik dalam hal bahasa maupun kebijakan pendukung yang diterapkan oleh pemerintah Filipina sendiri.

Hal yang tidak kalah penting adalah tindakan dari ASEAN sendiri untuk mengikutsertakan masyarakat dalam setiap pengambilan keputusannya hingga tujuan membentuk ASEAN yang berorientasi masyarakat dapat benar-benar tercapai. Apalagi mengingat dalam hasil survei yang dilaksanakan Pusat Kajian ASEAN 2015, diketahui bahwa harapan masyarakat atas Masyarakat ASEAN adalah dapat menjadi peluang dan memberikan manfaat bagi mereka. Oleh karena itu masyarakat ASEAN 2015 akan menjadi lebih strategis jika menangkap beberapa keterbatasan pengetahuan tersebut sebagai sebuah tantangan bersama. Sehingga, tidak hanya pemberdayaan ekonomi secara umum yang diwacanakan namun juga sebuah ikhtiar untuk memiliki sikap tegas tentang tentang berbagai peluang sekaligus akses perempuan dalam era masyarakat ASEAN yang dimulai tahun 2015 mendatang.

\section{Catatan Kritis}

Di dalam studi ini, setiadaknya tercatat beberapa celah yang masih perlu untuk dikaji secara mendalam dalam upaya membangun masyarakat ASEAN yang kontributif terhadap pembangunan ekonomi regional. Terlebih jika wacana ini dikatikan dengan isu gender, salah satu yang menjadi persoalan terutama adalah tentang perempuan buruh migran. Tingginya jumlah perempuan buruh migran di luar negeri atau bahkan negara sesama ASEAN sering terkait pula dengan meningkatnya jumlah kemiskinan itu sendiri. Kemiskinan yang berdampak pada keterbatasan pemenuhan kebutuhan sering memunculkan spekulasi untuk memanfaatkan peluang-peluang pekerjaan yang disediakan. Bekerja di luar negeri sering dimaknai sebagai upaya untuk mempercepat mendapatkan penghasilan yang berlipat. Akan tetapi karena ketrampilan dan kualifikasi yang dimiliki terbatas maka jenisjenis pekerjaan yang dipilih juga terbatas. Buruh migran yang dalam logika kerja tidak memilki persyaratan profesionalisme yang kompleks lantas menjadi pilihan. Pekerjaan buruh hanya membutuhkan kesediaan untuk membiasakan diri melakukan aktivitas yang sama setiap saatnya sehingga akan terampil dengan sendirinya. Jenis pekerjaan ini di luar negeri yang kemudian terjangkau adalah menjadi pembantu rumah tangga. Pekerjaan rumah tangga yang sering diidentikan dengan perempuan lantas memaksa perempuan untuk yang lebih aktif berpartisipasi.

Namun ternyata konsekuensi dari bekerja sebagai pembantu rumah tangga di luar negeri ini tidak sederhana. Ketika mereka berhasil menyelesaikan tugas-tugasnya tidak lantas menghindarkan diri dari masalah. Persoalan budaya, komunikasi dan sejumlah kebiasaan di negara berbeda ternyata lebih banyak berpengaruh terhadap keselamatan mereka sebagai pekerja di luar negeri. Namun karena latar belakang sosial yang dimiliki para perempuan buruh migran tersebut tidak cukup sebagai modal diri dalam bernegosiasi di banyak hal, maka para perempuan buruh migran tersebut justru sering terjebak pada risiko yang sangat menyulitkan. Kesenjangan 
antara orientasi meningkatkan kesejahteraan ekonomi dengan kapasitas sosial yang dimiliki inilah yang kemudian menjadi catatan penting dalam masyarakat ASEAN 2015 ini. Logika kesepakatan regional yang sudah mempertimbangkan aspek sosial selain kepentingan ekonomi akan menjadi sangat relevan untuk diterapkan dalam fenomena perempuan buruh migran ini. Sehingga tingginya jumlah perempuan buruh migran yang dikirimkan tidak hanya menguntungkan negara karena mengalirkan banyak devisa. Namun secara sosial juga penting untuk mempertimbangkan kompensasi yang seharusnya didapatkan perempuan dalam konteks kapasitas dan kesejahteraan.

Hal lainnya adalah terkait dengan komitmen politik masyarakat ASEAN 2015 ini dalam melihat fenomena ketenagakerjaan. Asumsi dikotomi negara utara-selatan masih menjadi persoalan mendasar yang kemudian membentuk mental subordinat bagi masyarakat negara berkembang itu sendiri. Secara umum misalnya, negara-negara seperti Indonesia, Filipina dan Bangladesh sering diasumsikan sebagai negara pengirim tenaga kerja yang berlawanan dengan dengan negara seperti Malaysia, Kuwait dan Arab Saudi (Tambunan 2007). Hal ini disebabkan oleh konstruksi yang sering menyatakan bahwa negaranegara pengirim tenaga kerja tersebut masih terbelakang dalam pencapaian pertumbuhan ekonominya. Sehingga kebutuhan tenaga kerja murah yang dimiliki negara-negara dengan pertumbuhan ekonomi yang baik menjadi mudah untuk disediakan oleh negara pengirim. Kondisi ini juga mempengaruhi keterbatasan negara-negara pengirim termasuk Indonesia tersebut dalam melindungi masyarakatnya saat harus menjadi buruh migran. Posisi tawar negara yang rendah lantas berdampak kurang menguntungkan juga bagi para pekerja migran, terutama perempuan. Oleh karena itu, terbentuknya masyarakat ASEAN 2015 dapat menjadi peluang juga dalam menghancurkan dikotomi antara negara pengirim dan negara penerima tenaga kerja. Jangan sampai dikotomi tersebut justru menghadirkan dikotomi dalam bentuk-bentuk baru di level regional mengingat relasi Indonesia dan Malaysia juga cukup nampak bertolak belakang dalam kasus buruh migran perempuan.

Maka, ide dan gagasan untuk mencapai pertumbuhan ekonomi di dalam negaranegara ASEAN secara bersama-sama dapat dijadikan sebagai modal untuk meningkatkan posisi tawar domestik di level global. Sehingga seandainya peminat untuk menjadi buruh migran terutama pada kelompok perempuan itu sendiri masih tinggi, setidaknya negara tetap memilki kebijakan yang dapat digunakan sebagai bentuk perlindungan yang jelas bahkan jika itu terjadi dalam lingkup regional sekalipun.

\section{Daftar Pustaka}

Anich Rudolf, Crush Jonathan, Melde Susane, Oucho o John. (2014). A New Perspective on Human Mobility in the South. New York London: . Springer.

ASEAN Secretariat. (2003). Declaration of ASEAN Concord II (Bali Concord II). (Online), (http:// www.asean.org/news/item/declaration-ofasean-concord-ii-bali-concord-ii, diakses 20 Desember 2014)

Badan Statistik Indonesia, Jumlah Angkatan Kerja, Penduduk Bekerja, Pengangguran, TPAK dan TPT, 1986-2013. (Online), (http://www.bps.go.id/tab_sub/view. php?kat $=1 \&$ tabel $=1 \&$ daftar $=1 \&$ id subyek $=06 \&$ notab $=5$ diakses pada 20 Desember 2014)

BNP2TKI. , (2014). , Data Penempatan Tenaga Kerja Indonesia (TKI). (Online), (http:// www.bnp2tki.go.id/uploads/data/data_0511-2014_031627_Laporan_Pengolahan_ Data_PENEMPATAN_BNP2TKI_S.D_ OKTOBER_2014.pdf)

Chafezt Janet Saltzman. (2006). Handbook of the Sociology of Gender. USA: Springer 
Donahoe Debra Anne. (1999). Measuring Women's Work in Developing Countries. Population adan Development Review. (Online), Volume 25, No. 3, 1999. (http:// www.jstor.org/stable/172347, diakses 10 Desember 2014)

International Labour Organzation. (2013). Labour and Social Trends in Indonesia 2013: Reinforcing the Role of Decent Work in Equitale Growth. Jakarta: ILO, hlm. 63.

International Organization for Migration. (2010). International Migration and Migrant Workers' Remittances in Indonesia: Findings of Baseline Surveys of Migrant Remitters and Remittance Beneficiary Households. Makati City, Philipines: IOM .

IPNN.COM. (2013). Penempatan TKI Capai 512.168. (Online), (http://www.jpnn.com/ $\mathrm{read} / 2014 / 04 / 01 / 225678 / 2013,-P e n e m p a t a n-$ TKI-Capai-512.168-, diakses 20 Desember 2014)

Komisi Nasional Anti Kekerasan terhadap Perempuan. (2003). Penyiksaan Sistematis di Dalam dan Luar Negeri. Laporan Indonesia kepada Pelopor Khusus PBB untuk Hak Asasi Migran. Jakarta: KOMNAS Perempuan dan Solidaritas Perempuan/ CARAM Indonesia.

Komnas Perempuan (2006). National Consulttion: Indonesian NGOs and Komnas Perempuan
With United Nation Special Rapporteur on the Human Rights of Migrants (Proceeding). Jakarta.: Komnas Perempuan.

Praditya, Ilyas Istianur. (2013). Malaysia Masih Jadi Negara Pengguna TKI Terbanyak di 2013, (Online), (http://bisnis.liputan6.com/ $\mathrm{read} / 794211 /$ malaysia-masih-jadi-negarapengguna-tki-terbanyak-di-2013, diakses 20 Desember 2014)

Pettman, Jan Jindy. (2001). Gender Issues (dalam The Globalization of World Politics: An Introduction to Interntional Relations. New York: Oxford University.

Rabrindranath, Ariana Leon. (2013). "Migrant Women Workers in Southeat Asia Challenges, Programs and Best Practices", Global Gender Program Occasional Report \#3, Oktober 2013, hal. 1. (Online), (http:// www.gwu.edu/ ggi/assets/docs/ggpop3. pdf diakses 20 Desember 2014)

Shiva Vandana. (1997). Bebas dari Pembangunan. Jakarta: Yayasan Obor Indonesia.

Sunarijati Ari. (2007). Pemiskinan Terhadap Buruh Perempuan. Jurnal Perempuan No. 56 Edisi November.

Tambunan Rita Olivia. (2007). Buruh Perempuan Indonesia dan Gejala Globalisasi. Jurnal Perempuan No. 56 Edisi November.

Tong Putnam. (1998). Feminist Thought. Yogyakarta. Jalasutra: University Press. 